\title{
Local knowledge and perceptions of vulture conservation in communities living adjacent to the northern Gonarezhou National Park, Zimbabwe.
}

\author{
Samuel F. Mdhlano, Edson Gandiwa*, Never Muboko and Clayton Mashapa
}

School of Wildlife, Ecology and Conservation, Chinhoyi University of Technology, Private Bag 7724, Chinhoyi, Zimbabwe

* Corresponding author: egandiwa@gmail.com

http://dx.doi.org/10.4314/vulnew.v74i1.1

\begin{abstract}
Vulture populations are declining globally largely due to deliberate and unintentional persecution and poisoning of animal carcasses which the birds consume. The objectives of this study were to: (i) assess local people's knowledge and perceptions of vultures and their ecological importance and (ii) determine the socio-cultural uses of vulture body parts in communities adjacent to the northern Gonarezhou National Park, south-eastern Zimbabwe. Semi-structured questionnaires were administered through interviews with randomly selected household representatives $(n=81)$ in August 2016. Our results showed that the majority of study respondents, $72.9 \%(n=59)$ reported the need to conserve vultures for their socio-ecological importance to the local communities. Respondents acknowledged the importance of vultures as agents of cleaning the environment, hence maintaining ecosystem health. However, a concern for vulture population decline due to poisoning was reported by most respondents of $71.6 \%(n=58)$. Vulture's organs were reported to be used mostly to enhance dreaming or having visions about the future followed by healing and lastly magic use. We recommend enhanced conservation awareness and education on vultures' conservation and restrictions on access to and use of hazardous chemicals which may likely be used in poisoning wildlife.
\end{abstract}

\section{Introduction}

Vultures are birds of prey and keystone species. They are important indicators of terrestrial biodiversity and the environmental health of different landscapes (Gregory \& van Strien 2010). Although the importance of vultures has always been recognised scientifically and culturally, their extensive protection began to be practised on a landscape level following studies indicating that protected areas are at times insufficient without scavengers to represent and protect the world's diversified wildlife (Caro 2001, Rodrigues et al. 2004). Although vulture populations frequently occur inside protected areas, several studies have also emphasised the importance of conservation of areas outside protected areas as they can represent a significant part of vulture home ranges (Gálvez et al. 2013, Phipps et al. 2013).

Recent studies have revealed that vulture populations have declined, particularly in Africa (Virani et al. 2011, Ogada et al. 2012, Murn et al. 2016, Ogada et al. 2016). Accordingly, most species are now listed on 
the International Union for the Conservation of Nature and Natural Resources (IUCN) Red List as Endangered or Critically Endangered (IUCN 2016). In southern Africa, poisoning is claiming the lives of most vulture species (McNutt \& Bradley 2014, Murn \& Botha 2017). This is either deliberately as poacher's lace carcasses with poison to target vultures so that they do not expose poaching activities (Ogada et al. 2016), or for ritual purposes (Groom et al. 2013, McKean et al. 2013). In some cases, vulture poisoning is unintentional (secondary poisoning), whereby vultures consume poisoned baits targeting predators (Simmons 1995).

In 2013, a mass poisoning of vultures was reported in Gonarezhou National Park, Zimbabwe, where about 200 vultures had died after eating from a poisoned elephant (Loxodonta africana) carcass (Groom et al. 2013). Groom et al. (2013) suggested that this was one of the largest mass poisonings recorded in the country. In Hwange National Park, in north-western Zimbabwe, an unknown number of vultures succumbed to poisoning after they had consumed elephant carcasses killed by cyanide poisoning (Muboko et al. 2014). In light of such events, and to try and prevent them to progress vulture conservation in Africa, particularly southern Africa, it is necessary to understand community perceptions towards vultures, their sociocultural significance and the drivers of poison use.

Therefore, the objectives of this study were to: (i) assess local people's knowledge and perceptions of vultures and their ecological importance and (ii) determine the sociocultural uses of vulture body parts in communities adjacent to the northern Gonarezhou National Park, south-eastern Zimbabwe. An important assumption in this study was that human communities, especially those living in and around protected areas, often have important and long-standing relationships with these areas, giving local people particular knowledge about the environments in which they live (Trakolis 2001, Huntington 2011).

\section{Materials and Methods}

\section{Study area}

The study was conducted in communities adjacent to the northern Gonarezhou National Park, south-eastern Zimbabwe. Established in the early 1930s as a Game Reserve, Gonarezhou National Park was upgraded to a national park under the Parks and Wildlife Act of 1975. The study area forms part of the Great Limpopo Transfrontier Conservation Area. The Gonarezhou National Park is the second largest national park in Zimbabwe after Hwange National Park and covers an area of approximately $5000 \quad \mathrm{~km}^{2}$. Gonarezhou National Park experiences a typically semiarid climate, receiving an average annual precipitation of $466 \mathrm{~mm}$ and temperature range of $18{ }^{\circ} \mathrm{C}$ to $34{ }^{\circ} \mathrm{C}$ (Gandiwa 2011). The park supports a wide range of wildlife, including buffalo (Syncerus caffer), elephant, giraffe (Giraffa camelopardalis), zebra (Equus quagga), lion (Panthera leo), leopard (Panthera pardus), and spotted hyena (Crocuta crocuta) (ZPWMA 2011). Vulture species in the study area include the Hooded (Necrosyrtes monachus), Lappet-faced (Torgos tracheliotos), White-backed (Gyps africanus), and White-headed (Trigonoceps occipitalis) while Cape Vultures (Gyps coprotheres) are occasional visitors (Childes \& Mundy 2001, Groom et al. 2013). Three communities namely, Chibwedziva and Chizvirizvi falling under the Chiredzi district, and Mutandahwe falling under the Chipinge district, adjacent to the northern Gonarezhou National Park, southieastern Zimbabwe were selected for the study (Figure 1).

The study area is dominated by the Shangaan people and communities adjacent to the northern Gonarezhou National Park 
practice a combination of subsistence farming that includes livestock and cash crop production (Gandiwa 2011). Maize (Zea mays) and sorghum (Sorghum bicolor) are the main crops grown for home consumption, whereas cotton (Gossypium spp.) is mainly grown for commercial purposes.

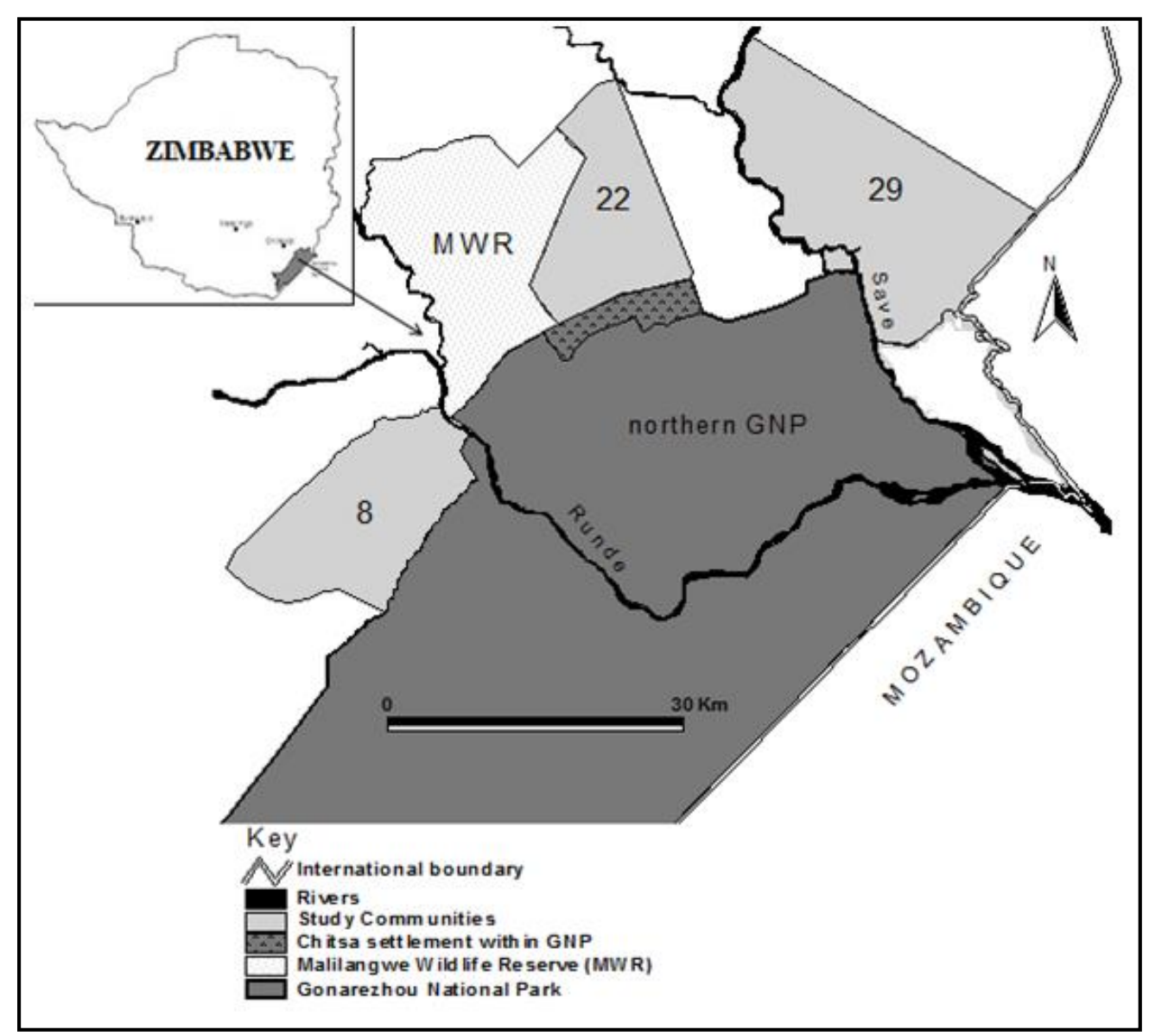

Figure 1: Location of the three study communities adjacent to the northern Gonarezhou National Park, southeastern Zimbabwe. Notes: $8=$ Chibwedziva, $22=$ Chizvirizvi and $29=$ Mtandahwe.

The main livestock found in this area include cattle (Bos taurus), donkeys (Equus asinus), goats (Capra hircus), poultry and sheep (Ovis aries). The communities who live in the study area manage their natural resources and practice community-based conservation under the Communal Areas Management Programme for Indigenous Resources (CAMPFIRE) (Martin 1986). CAMPFIRE provide the study communities with financial and non-financial benefits derived from the sustainable utilisation of wildlife resources and these benefits generally encompass boreholes, road rehabilitation, grinding mills, and construction of educational and health infrastructure among other communal projects.

\section{Data collection and analyses}

Data on local perceptions of vulture conservation were collected from 81 household respondents randomly chosen from three communal areas, i.e., Chibwedziva $(n=$ 27), Chizvirizvi $(n=27)$ and Mutandahwe ( $n$ $=27$ ) in August 2016. This sample comprised of $62 \%(n=50)$ males and $38 \%(n=31)$ females. About $89 \%(n=72)$ of the respondents had at least primary education and agriculture was the most common type of 
livelihood (Table 1). Random selection was numbers from a hat that corresponded to the achieved through picking pieces of paper with households from the different study villages.

Table 1: Socio-economic and demographic profiles of surveyed participants across three communities in southeast Zimbabwe.

\begin{tabular}{|c|c|c|c|c|}
\hline \multirow[t]{2}{*}{ Variable } & \multicolumn{3}{|c|}{ Study community } & \multirow[t]{2}{*}{ Total } \\
\hline & Chibwedziva & Chizvirizvi & Mutandahwe & \\
\hline & $\#(\%)$ & $\#(\mathrm{n})$ & $\#(\%)$ & $\#(\%)$ \\
\hline \multicolumn{5}{|l|}{ Gender } \\
\hline Female & $13(48.1)$ & $13(48.1)$ & $5(18.5)$ & $31(38.2)$ \\
\hline Male & $14(51.9)$ & $14(51.9)$ & $22(81.5)$ & $50(61.8)$ \\
\hline \multicolumn{5}{|l|}{ Age } \\
\hline $18-25$ & $5(18.5)$ & $9(33.3)$ & $8(29.6)$ & $22(27.1)$ \\
\hline $26-50$ & $19(70.4)$ & $13(48.1)$ & $15(55.6)$ & $47(58.0)$ \\
\hline $51+$ & $3(11.1)$ & $5(18.5)$ & $4(14.8)$ & $12(14.8)$ \\
\hline \multicolumn{5}{|l|}{ Level of education } \\
\hline None & 0 & $7(25.9)$ & $2(7.4)$ & $9(11.1)$ \\
\hline Primary & $16(59.3)$ & $5(18.5)$ & $13(48.1)$ & $34(42.0)$ \\
\hline Secondary & $9(33.3)$ & $14(51.9)$ & $10(37)$ & $33(40.7)$ \\
\hline Tertiary & $2(7.4)$ & $1(3.7)$ & $2(7.4)$ & $5(6.2)$ \\
\hline \multicolumn{5}{|l|}{ Religion } \\
\hline Christian & $14(51.9)$ & $16(59.3)$ & $19(70.4)$ & $49(60.5)$ \\
\hline Africa tradition & $13(48.1)$ & $10(37)$ & $7(25.9)$ & $30(37.0)$ \\
\hline Muslim & 0 & $1(3.7)$ & 0 & $1(1.2)$ \\
\hline None & 0 & 0 & $1(3.7)$ & $1(1.2)$ \\
\hline \multicolumn{5}{|c|}{ Source of livelihood } \\
\hline Crop production & $25(92.6)$ & $24(88.9)$ & $24(88.9)$ & $73(90.1)$ \\
\hline Livestock rearing & $10(37)$ & $19(70.4)$ & $17(63)$ & $46(56.8)$ \\
\hline Employed & $1(3.7)$ & $7(25.9)$ & $16(59.3)$ & $24(29.6)$ \\
\hline Own a business & $8(29.6)$ & $3(11.1)$ & $3(11.1)$ & $14(17.3)$ \\
\hline \multicolumn{5}{|l|}{ Period of residence } \\
\hline $0-2$ years & 0 & $3(11.1)$ & $1(3.7)$ & $4(5.0)$ \\
\hline $3-5$ years & $1(3.7)$ & $3(11.1)$ & $3(11.1)$ & $7(8.6)$ \\
\hline $6+$ years & $26(96.3)$ & $21(77.8)$ & $23(85.2)$ & $70(86.4)$ \\
\hline Head of family & $19(70.4)$ & $15(53.6)$ & $18(66.7)$ & $52(63.6)$ \\
\hline
\end{tabular}

The study mainly targeted household heads to respond to the questionnaires, however in their absence, a resident adult ( $\geq 18$ years) in a household had the opportunity to participate in the interview (Gandiwa et al. 2013). The interviews were held conditionally upon an individual's willingness to participate and the presence of a translator encouraged the respondents to openly answer the questions under investigation as well as providing information regarded as sensitive. Study respondents were also assured of anonymity of responses. Each interview was conducted at a respondent homestead and it took about 20 to 30 minutes to complete. Of the questions asked, most were open ended so as to tap into the perceptions of the villagers in a form that was not a priori (Gandiwa et al. 2013). The study questionnaire was largely informed by Reson (2012) and included questions on (i) local people's knowledge and perceptions of vultures and their ecological importance and (ii) the socio-cultural uses of vulture body parts. The questionnaire had specific terms related to the study objectives and questions were carefully constructed, worded in a way respondents could understand and presented to each respondent in exactly the same way so as to avoid bias and lead to particular answers (Kasunic 2005). The questionnaire was pre- 
tested in a community adjacent to the study area, and where necessary, questions were reframed for clarity. Necessary permission to conduct the study was sought from the relevant authorities in advance and respondents were informed of the planned interviews one to two days in advance. Frequencies were used to summarise data on respondents socio-demographic variables and knowledge and perceptions of vultures and their ecological importance and presented in tables and graphs.

\section{Results}

Knowledge and perceptions of vultures and their ecological importance
The majority of study respondents $(72.9 \%, n=$ 59) reported the need to conserve vultures for their socio-ecological importance to the local communities, which include their role in cleaning the environment $(72 \%, n=58$; Table 2). Vultures were also reported as an important indicator of wild animal carcasses and also being an important species for tourism (Fig. 2). About half of the respondents $(50.4 \%, n=$ 41) highlighted concerns over vulture population decline whereas $42 \%(n=34)$ of the study respondents perceived that vulture population decline was attributed to the poisoning of carcasses to deliberately kill vultures. About $65 \%(n=53)$ of the respondents reported the need to educate local people about vulture conservation and how to protect their breeding habitat.

Table 2: Knowledge and perceptions of vultures and their ecological importance amongst three communities in south-eastern Zimbabwe.

\begin{tabular}{|c|c|c|c|c|}
\hline & \multicolumn{3}{|c|}{ Extent of agreement by respondent } & \multirow[b]{2}{*}{ Total } \\
\hline & Chibwedziva & Chizvirizvi & Mutandahwe & \\
\hline & $\#(\%)$ & $\#(\%)$ & $\#(\%)$ & $\#(\%)$ \\
\hline $\begin{array}{l}\text { Vultures should be conserved for their socio- } \\
\text { ecological importance }\end{array}$ & $21(77.8)$ & $18(66.7)$ & $20(74.1)$ & $59(72.9)$ \\
\hline $\begin{array}{l}\text { Vultures combat spread of diseases across other } \\
\text { carnivorous animals }\end{array}$ & $16(59.3)$ & $20(74.1)$ & $22(81.5)$ & $58(71.6)$ \\
\hline $\begin{array}{l}\text { People are willing to participate in planned future } \\
\text { vulture conservation awareness programs }\end{array}$ & $15(55.6)$ & $19(70.4)$ & $19(70.4)$ & $53(65.5)$ \\
\hline $\begin{array}{l}\text { It is important to educate people about vulture } \\
\text { conservation and to protect their breeding habitat }\end{array}$ & $13(48.1)$ & $21(77.8)$ & $19(70.4)$ & $53(65.5)$ \\
\hline $\begin{array}{l}\text { Population decline of vultures in the study area now as } \\
\text { compared to the past }\end{array}$ & $12(43.7)$ & $15(55.6)$ & $14(51.9)$ & $41(50.6)$ \\
\hline $\begin{array}{l}\text { Vultures feed on poisoned carcasses leading to their } \\
\text { deaths in the study area }\end{array}$ & $9(33.3)$ & $16(59.3)$ & $15(55.6)$ & $40(49.4)$ \\
\hline $\begin{array}{l}\text { People poison carcasses to target vultures and this is } \\
\text { causing vulture population decline in the study area }\end{array}$ & $10(37)$ & $14(51.9)$ & $10(37)$ & 34 (41.9) \\
\hline $\begin{array}{l}\text { Vultures sometimes compete with other scavengers } \\
\text { for carcasses and eventually get killed }\end{array}$ & $16(59.3)$ & $6(22.2)$ & $4(14.8)$ & $26(32.1)$ \\
\hline Some vulture species kill livestock & $5(18.5)$ & $11(40.7)$ & $6(22.2)$ & $22(27.2)$ \\
\hline
\end{tabular}




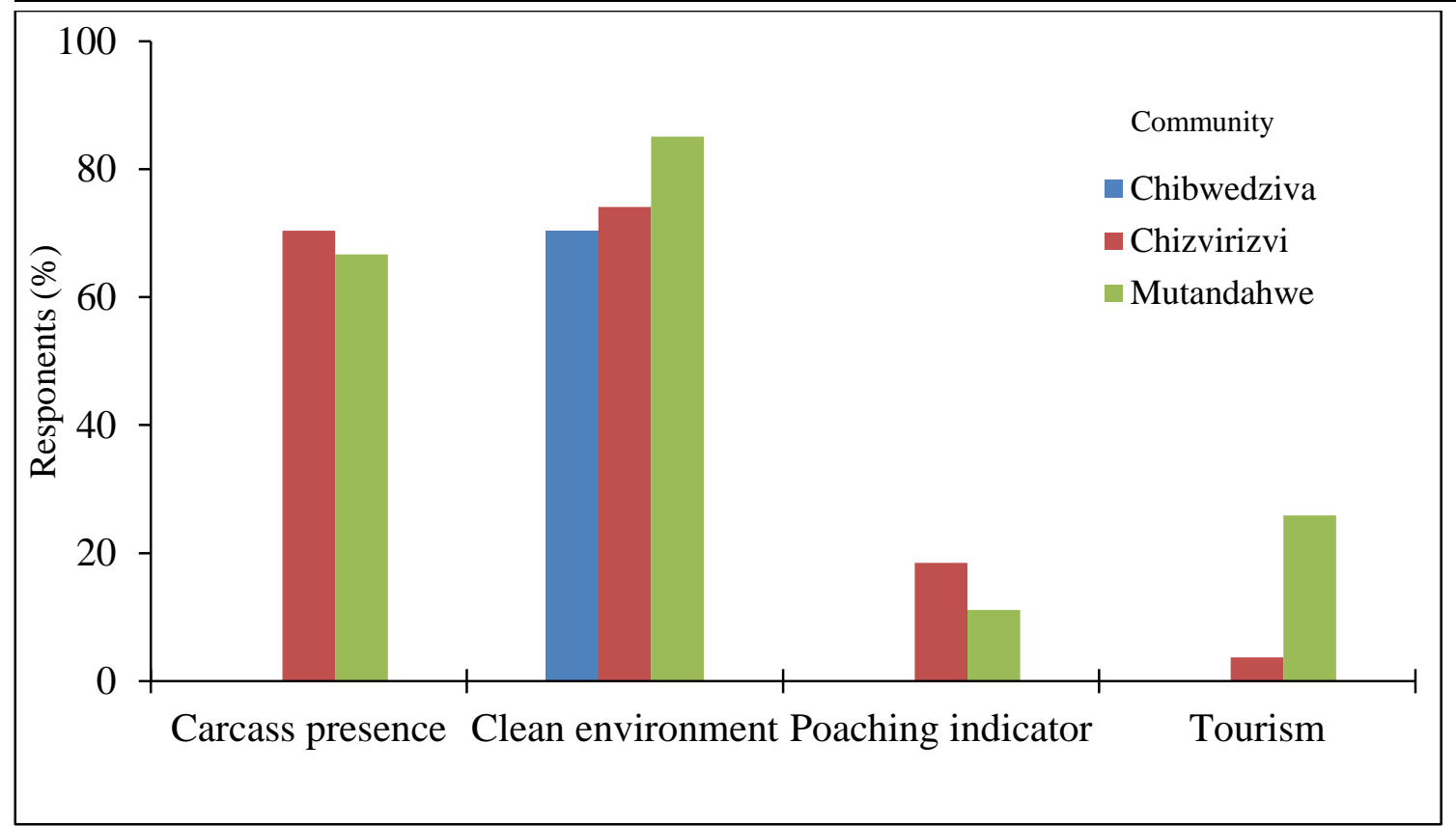

Figure 2: Perceived importance of vultures in ecosystems by respondents from three communities in south-eastern Zimbabwe (81 respondents).

\section{Socio-cultural uses of vulture body parts}

Vulture brain organ use had the highest responses in terms of use followed by bones and feathers, whereas hearts of vultures were the least reported (Figure 3). Vulture's organs were reported to be mostly used to enhance dreaming or having visions about the future followed by healing and, lastly, magic use (Figure 4).

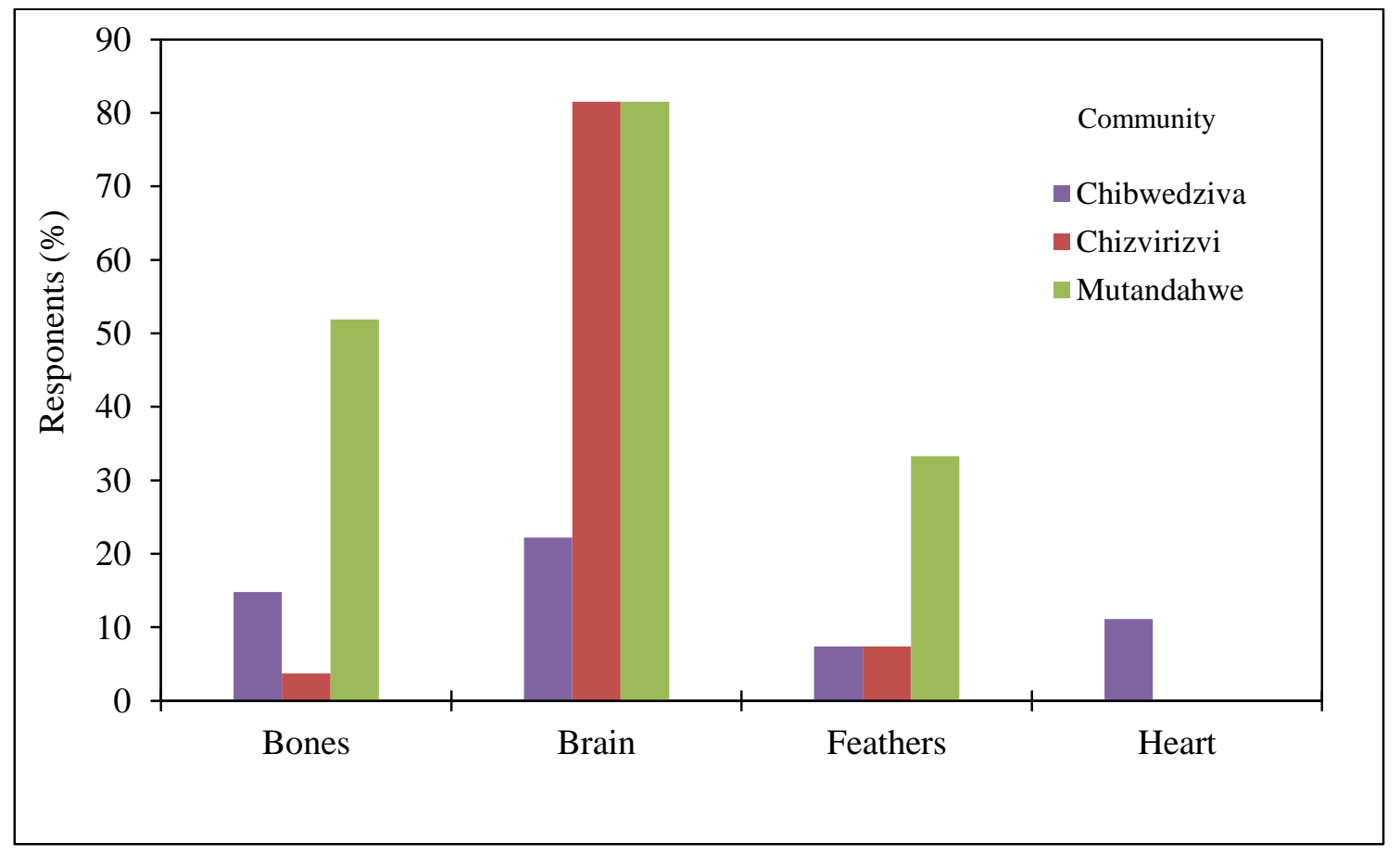

Figure 3: Vulture body parts used for social or cultural reasons or other benefits across three communities in south-eastern Zimbabwe (81 respondents). 


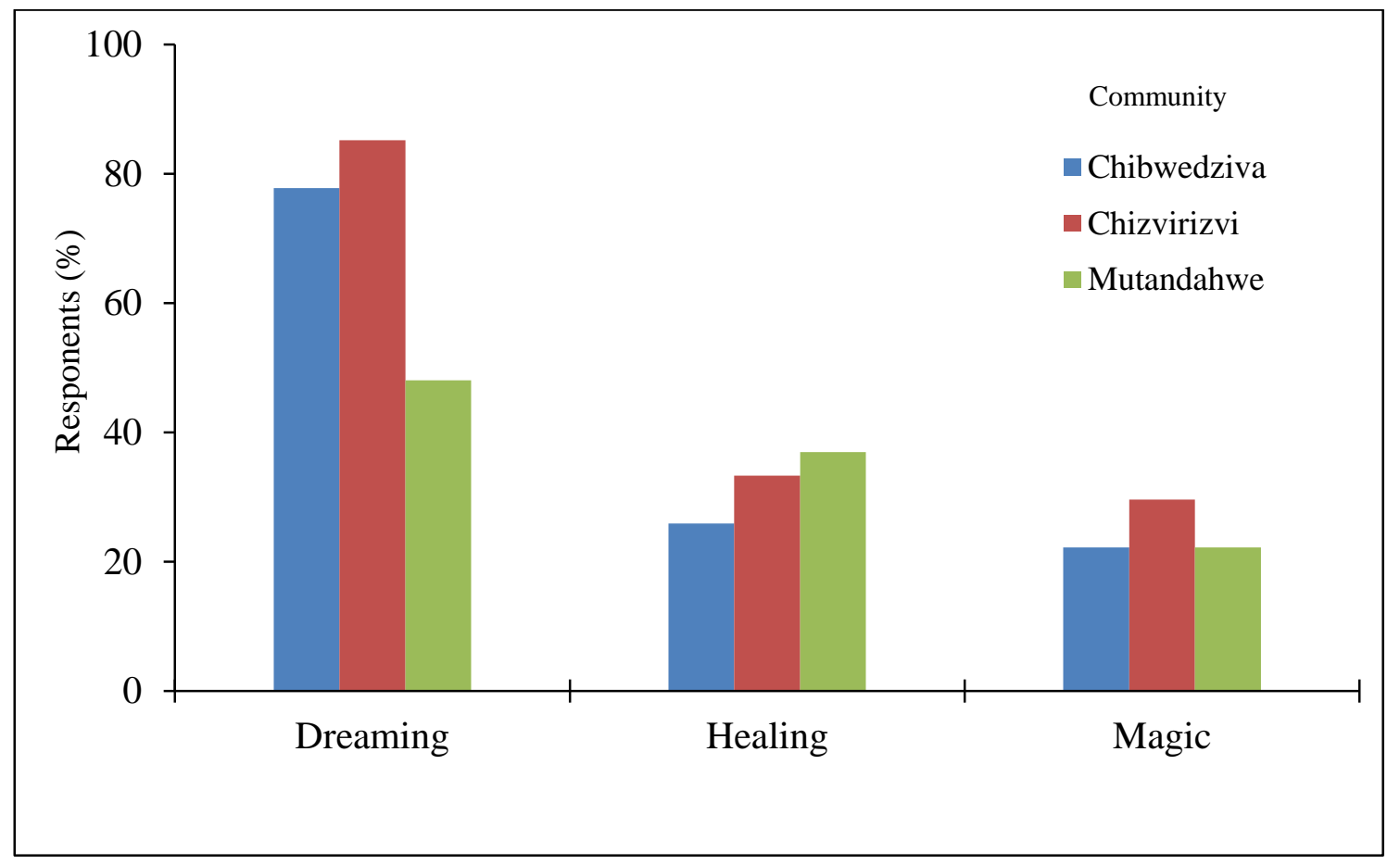

Figure 4: Socio-cultural uses of vulture body parts across three communities in south-eastern Zimbabwe (81 respondents).

\section{Discussion}

Our results showed that most respondents perceived vultures as important biological cleaners of the ecosystem, thus playing an important role in keeping the environment healthy. This finding concurs with Whelan et al. (2008) who reported that vultures play a significant ecological role as nature's garbage disposers, thus helping to keep the ecosystem healthy and clean. Vultures are highly specialised to rapidly dispose of large carcasses and play a critical role in nutrient cycling, leading other scavengers to carcasses and reducing the risk of contamination by pathogens (Houston \& Cooper 1975, Parmenter \& Macmahon 2009, Wenny et al. 2011).

Despite the fact that vultures dispose of rotting carcasses and help prevent the spread of deadly diseases, their survival in natural ecosystems is increasingly being threatened. Intentional or unintentional human interference has pushed vulture species to the brink of extirpation especially through consumption of poisoned carcasses eventually killing the species in large numbers (e.g. Groom et al. 2013, McNutt \& Bradley 2014) thereby reducing the population of vultures in the natural ecosystem

As vultures are attracted to carcasses, they are perceived to play an indirect role in assisting authorities identify poaching activities in protected areas. This is particularly true for large herbivores such as elephant and rhinoceros; when poached for their trophies, these carcasses attract vultures that can provide law enforcement staff with insights to carcasses and/or poaching incidences. Since vultures attract attention to illegal hunting activities, some illegal hunters perceive them as enemies. Thus, a common practice of some illegal hunters is to poison carcasses with the intention of killing vultures (e.g. Groom et al. 2013, Ogada et al. 2016) as a way to minimise detection by law 
enforcement staff. Vultures are also indirectly poisoned by local farmers and hunters. For instance, in some African countries farmers often leave poisoned meat or carcasses on their farmlands to reduce predator populations. These carcasses unfortunately also attract vultures, thus leading to their demise (Ogada et al. 2012).

Our results highlight the socio-cultural uses of vulture body parts in the study area, similar to what has been reported in other earlier studies (e.g. McKean et al. 2013, Williams et al. 2014). Some body organs of vultures are perceived to have magical, healing and predictive or fortune-telling powers in some African traditional belief systems (Reson 2012, Groom et al. 2013). However, our study showed variations in traditional beliefs and uses of vulture body parts across the three study communities suggesting a contextual cultural diversity.

An important finding in our study was that the most of the respondents were willing to participate in vulture conservation programmes. This is valuable given that our sample had a high percentage of educated people, hence, the appreciation of the value of conservation of the species. Vulture conservation programmes could also include conservation education programmes which might help reduce the traditional practice where vultures are hunted for their body parts. Moreover, campaigns to reduce use of poisons in illegal hunting of wildlife needs to be strengthened so as to reduce the impacts on non-target species in the ecosystem.

\section{Conclusion}

Our study shows that study respondents were highly knowledgeable of the importance of vultures in the ecosystem and related potential benefits that may accrue from tourism, hence the importance of conserving the species. However, our results suggest that vulture species are still threatened by poisoning and illegal harvesting for body parts for sociocultural uses. We recommend that local authorities and the Gonarezhou National Pak management: (i) enhance education and awareness campaigns on the ecological role of vultures, species diversity and demystify notions related to vulture body parts for sociocultural uses; (ii) collaborate with other government departments and stakeholders in restricting access to and use of hazardous chemicals which may likely be used in poisoning wildlife including vultures, (iii) conduct ecosystem-based research on vulture species population trends, breeding and distribution status in the protected area and adjacent communities and (iv) undertake a survey to understand the extent of the illegal trade in vulture products including sources and market dynamics in the greater ecosystem.

\section{Acknowledgements}

We thank the Gonarezhou Conservation Project for the support, village authorities for the permission, and local communities for participating in this study. Comments from two reviewers helped improve earlier drafts of this manuscript.

Key words: education, ecosystem health, poisoning, socio-cultural use, traditional belief

\section{References}

Caro, T. 2001. Species richness and abundance of small mammals inside and outside an African national park. Biological Conservation 98: 251-257.

Childes, S. L. \& Mundy, P. J. 2001. Important Bird Areas of Zimbabwe. In: Fishpool, L. D. C. \& Evans, M. I. (Eds). Important Bird Areas in Africa and associated islands: Priority sites 
for conservation, pp. 1025-1042. Pisces Publications and BirdLife International, Newbury and Cambridge.

Gálvez, N., Hernández, F., Laker, J., Gilabert, H., Petitpas, R., Bonacic, C., Gimona, A., Hester, A. \&Macdonald, D. W. 2013. Forest cover outside protected areas plays an important role in the conservation of the Vulnerable guiña Leopardus guigna. Oryx 47: 251-258.

Gandiwa, E. 2011. Preliminary assessment of illegal hunting by communities adjacent to the northern Gonarezhou National Park, Zimbabwe. Tropical Conservation Science 4: 445467.

Gandiwa, E., Heitkönig, I. M., Lokhorst, A. M., Prins, H. H. T. \& Leeuwis, C. 2013. Illegal hunting and law enforcement during a period of economic decline in Zimbabwe: A case study of northern Gonarezhou National Park and adjacent areas. Journal for Nature Conservation 21(3): 133-142.

Gregory, R. D. \& van Strien, A. 2010. Wild bird indicators: using composite population trends of birds as measures of environmental health. Ornithological Science 9: 3-22.

Groom, R. J., Gandiwa, E., Gandiwa, P. \& van der Westhuizen, H. J. 2013. A mass poisoning of White-backed and Lappet-faced vultures in Gonarezhou National Park. Honeyguide 59: $5-9$.

Houston, D. C. \& Cooper, J. E. 1975. The digestive tract of the whiteback griffon vulture and its role in disease transmission among wild ungulates. Journal of Wildlife Diseases 11: 306313.

Huntington, H. P. 2011. The local perspective. Nature 478: 182-183.

IUCN. 2016. The IUCN Red List of Threatened Species. Version 2016-2. Available at http://www.iucnredlist.org/. Accessed on 30 October 2016.

Kasunic, M. 2005. Designing an Effective Survey. Handbook CMU/SEI-2005-HB-004, Software Engineering Institute, Carnegie Mellon University. [Online]. Available: www. sei.cmu.edu/pub/documents/05.reports/pdf/05hb004.pdf

Martin, R.B. 1986. CAMPFIRE (Communal Areas Management Programme for Indigenous Resources). Department of National Parks and Wildlife Management publication. Government Printer, Harare.

McKean, S., Mander, M., Diederichs, N., Ntuli, L., Mavundla, K., Williams, V. \& Wakelin, J. 2013. The impact of traditional use on vultures in South Africa. Vulture News 65: 15-36.

McNutt, J. W. \& Bradley, J. 2014. Report on Kwando (Botswana) vulture poisoning investigation 16 November 2013. Vulture News 66: 35-41.

Muboko, N. \& Murindagomo, F. 2014. Wildlife control, access and utilisation: Lessons from legislation, policy evolution and implementation in Zimbabwe. Journal for Nature Conservation 22: 206-211.

Murn, C.\& Botha, A. 2017. A clear and present danger: impacts of poisoning on a vulture population and the effect of poison response activities. Oryx 52: 552-558. 
Murn, C., Mundy, P., Virani, M. Z., Borello, W. D., Holloway, G. J. \& Thiollay, J. M. 2016. Using Africa's protected area network to estimate the global population of a threatened and declining species: a case study of the Critically Endangered White-headed Vulture Trigonoceps occipitalis. Ecology and Evolution 6: 1092-1103.

Ogada, D. L., Keesing, F. \& Virani, M. Z. 2012. Dropping dead: causes and consequences of vulture population declines worldwide. Annals of the New York Academy of Sciences 1249: 57-71.

Ogada, D., Botha, A.\& Shaw, P. 2016. Ivory poachers and poison: drivers of Africa's declining vulture populations. Oryx 50: 593-596.

Parmenter, R. R. \& Macmahon, J. A. 2009. Carrion decomposition and nutrient cycling in a semiarid shrub-steppe ecosystem. Ecological Monographs 79: 637-661.

Phipps, W.L., Willis, S.G., Wolter, K., Naidoo, V., 2013. Foraging ranges of immature African white-backed vultures (Gyps africanus) and their use of protected areas in southern Africa. PLoS One 8 (1): e52813.

Reson, E. N. M. 2012. Assessing Maasai attitudes and perceptions toward vultures: A case study of resident Maasai around Maasai Mara National Reserve, Kenya. MSc Thesis, Clemson University, South Carolina.

Rodrigues, A. S., Andelman, S. J., Bakarr, M. I., Boitani, L., Brooks, T. M., Cowling, R. M., Fishpool, L. D., Da Fonseca, G. A., Gaston, K. J. \& Hoffmann, M. 2004. Effectiveness of the global protected area network in representing species diversity. Nature 428: 640-643.

Simmons, R. 1995. Mass poisoning of Lappetfaced Vultures in the Namib Desert. Journal of African Raptor Biology 10: 3.

Trakolis, D. 2001. Local people's perceptions of planning and management issues in Prespes Lakes National Park, Greece. Journal of Environmental Management 61: 227-241.

Virani, M. Z., Kendall, C., Njoroge, P. \& Thomsett, S. 2011. Major declines in the abundance of vultures and other scavenging raptors in and around the Masai Mara ecosystem, Kenya. Biological Conservation 144: 746-752.

Wenny, D. G., Devault, T. L., Johnson, M. D., Kelly, D., Sekercioglu, C. H., Tomback, D. F. \& Whelan, C. J. 2011. The need to quantify ecosystem services provided by birds. The Auk 128: $1-14$.

Whelan, C. J., Wenny, D. G. \& Marquis, R. J. 2008. Ecosystem services provided by birds. Annals of the New York Academy of Sciences 1134: 25-60.

Williams, V. L., Cunningham, A. B., Kemp, A. C. \& Bruyns, R. K. 2014. Risks to birds traded for African traditional medicine: a quantitative assessment. PloS ONE 9(8), e105397.

ZPWMA (Zimbabwe Parks and Wildlife Management Authority). 2011. Gonarezhou National Park Management Plan: 2011-2021. Zimbabwe Parks and Wildlife Management Authority, Harare. 